\title{
Feeling Close to Fellow Citizens in Hong Kong, Korea, Taiwan, and Thailand
}

\author{
Chau-kiu Cheung • Raymond Kwok-hong Chan • Wing-chung Ho
}

Accepted: 15 October 2013/Published online: 23 October 2013

(C) Springer Science+Business Media Dordrecht 2013

\begin{abstract}
Feeling close to fellow citizens in the city is a feature of social cohesion that is worth investigation among East Asian societies for exploring societal conditions for the closeness. Because of the variation of such conditions among the societies, differentials in the closeness among the societies are possible. As the variation of societal conditions can translate into differences in personal characteristics and experiences, such differences are likely to explain differentials in the closeness. This likelihood is a focus for the present study, which surveyed 4,087 adult citizens in Hong Kong $(n=681)$, South Korea ( $n=1,006)$, Taiwan $(n=1,200)$, and Thailand $(n=1,200)$. Results revealed significant differentials in the closeness among the societies, showing that it was highest in Thailand and lowest in Taiwan. Furthermore, these differentials were largely due to differences in personal and characteristics among citizens in the four societies. Among the significant predictors of the closeness, work-family conflict and the costliness of medical expense are two experiences. The two experiences, as well as other predictors, champion a conflict or social force explanation for citizens' closeness. Accordingly, conflict or social force that is incapacitating would estrange the incapacitated individual from others. The results and explanation imply that relieving work and family conflicts is relevant to lifting citizens' closeness. In conclusion, the East Asian societies manifested differentials in citizens' social cohesion, and the differentials are explicable by differentials in resources and conflicts among the societies.
\end{abstract}

Keywords Social cohesion $\cdot$ Social quality $\cdot$ East Asian $\cdot$ Work-family conflict $\cdot$ Job stress

C. Cheung $(\bowtie) \cdot$ R. K. Chan · W. Ho

Department of Applied Social Studies, City University of Hong Kong, Kowloon Tong, Hong Kong, China

e-mail: ssjacky@cityu.edu.hk 


\section{Introduction}

A citizen's feeling close to fellow citizens in a city is crucial for cooperation in sustaining the society and is thus an indicator of social quality (Keyes and Shapiro 2004). The closeness, nevertheless, tends to be weakening due to alienating social change (Diewald and Ludicke 2006). Just as the social change is likely to be differential in different societies, the closeness would be likely to differ among societies. As this presumed differential, nevertheless, is empirically uncharted, an empirical study would be worthwhile to tap the differential. Of concern about the examination of the differential is that among the newly developed East Asian societies of Hong Kong, South Korea, Taiwan, and Thailand. While these societies are undergoing rapid and dramatic social changes, they differ in the level and pattern of development (Castells 2000; Kim et al. 2008). The developmental differential makes the societies good cases for examining the differential in their citizens' feeling close to their fellow citizens. Essentially, social change forms the individual citizen's experiences, such as employment, conflict between work and family, and costliness of medicine (Brannen et al. 2009). These experiences supposedly reflect or mediate the effect of social change (Constantino et al. 2006; Extremera et al. 2007). Such supposition is the thrust of the present study, which is to show that personal experiences that reflect social change explain the differential in the closeness among the East Asian societies.

Feeling close to fellow citizens in the same city is an indicator of social cohesion that represents people similarity, identification, with and trust in one another (Bell 2009; Uzzell et al. 2002). Social cohesion is valuable because of its instrumental function for economic growth, political stability, protection, and safety (Dayton-Johnson 2003; Maloutas and Maloutas 2004). Meanwhile, social cohesion is in need of promotion because of its decline, due to the breakdown of the community and moral values, segregation, individualization, social fragmentation, and even terrorism (Forrest and Kearns 2001; Husband and Alam 2011; Lawler et al. 2009). As such, restoring or raising social cohesion is of vital policy concern, partly to cushion the disturbing impact of welfare retrenchment (Espvall and Dellgren 2008; Hulse and Stone 2007). The policy concern largely rests on the doctrines of communitarianism for maintaining cohesion and closeness within a common place of living (Crow 2002). Such doctrines expect to maintain care and moral order in society (Robinson 2005). Essentially, communitarianism posits that the community is optimal for gathering people, sustaining their living and cooperation, and securing flourishing (Tan 2003). The policy is to extend communitarianism from the community level to city and national levels (Miller and Fox 2007). This extension is necessary to prevent communitarianism and social cohesion form being too parochial, exclusive, alienating, and even derogatory against out-groups (Cheong et al. 2007; Crow 2002). Social cohesion at national level has hitherto been unclear among East Asian societies (Janmaat 2011). For this reason, unraveling the differential in social cohesion, in terms of closeness to fellow citizens serves to advance the understanding of social cohesion in the societies.

\section{Societal Differentials}

The differential among East Asian societies in the closeness has its root in differentials and demographic socioeconomic, political, and cultural characteristics of the societies. Salient among these characteristics supposed to sustain social cohesion or the closeness in Hong Kong may include ethnic Chinese homogeneity, close and dense living conditions, economic development or affluence, Confucian heritage, civil society, and safety (Estes 2002; 
Forrest et al. 2002; Loh and Foong 2005; Tang 2006; Wong 1995). In the first place, the most obvious impetus to social cohesion or the closeness is the physical and cultural closeness among citizens (Fararo and Skvoretz 2002). This impetus thus anticipates the influence of ethnic homogeneity and geographical proximity to the Hong Kong citizen's social cohesion and feeling close to the fellow citizen. The impetus would also rest on frequent interpersonal contact facilitated by the dense living condition (Laurence 2011; Wilkinson 2009). Such contact also hinges on income and other economic conditions (Wilkinson 2009). Therefore, economic development in Hong Kong would contribute to social cohesion there. Another influence would spring from cultural and institutional forces, such as Confucianism and civil society, which provide the structure for the nourishment of social cohesion (Crow 2002; Fukuyama 2001). Moreover, safety in society tends to be a basis for social cohesion, as it enables citizens to trust each other (Fukuyama 2001). In contrast, inequality, disparity, polarization, immigration, competitiveness, freedom, individualism, intransigence, sojourner mentality, cosmopolitanism, world citizenship, cynicism, the legitimacy crisis, and cultural desert in Hong Kong are societal conditions subversive of social cohesion or the closeness (Cartier 2008; Chan 2004; DeGolyer 2001; Delang and Lung 2010; Estes 2002; Ho and Chan 2003; Huang and Hsu 2005; Kuan and Lau 2002; Lin and Lin 2001; Ma 2009; Ng and Wong 1999; Overholt 2004; Sing 2006; Wong 1995). Most obviously, individualization is supposed to weaken social cohesion (Crow 2002). In a similar vein, cultural change that diverts citizens away from local society would dampen social cohesion (Crow 2002). Hence, cosmopolitanism, world citizenship, and sojourner mentality in Hong Kong is likely to subvert social cohesion. Apart from this, any conflict would be detrimental to social cohesion (Lawler et al. 2009). This means that the source of conflict in inequality, disparity, intransigence, competitiveness, cynicism, and the legitimacy crisis would impede social cohesion. In addition, the cultural desert would forbid social cohesion, which hinges on cultural capital and mobilization (Collins 2004). Consequently, Hong Kong has a mix of forces countenancing and impairing social cohesion or the closeness (see Table 1).

In South Korea, conditions favorable to social cohesion or the closeness include civil society, communitarianism, conservatism, Confucianism, and corporatism (Kim 2010; Lew et al. 2011; Shin 2012; Suh 2010; Westerman et al. 2007; Woo 2011). Most clearly, civil society that builds on communitarianism, conservatism, and Confucianism would function to sustain social cohesion (Campbell 2000; Crow 2002). The teachings of the ideologies exactly aim to secure harmony and social cohesion. Thus, social cohesion in South Korea has a strong cultural basis. Moreover, corporatist policy furnishes an institutional framework to group people in a cooperative way (Lawler et al. 2009). In contrast, societal conditions discouraging social cohesion or the closeness in South Korea include alienation, consumerism, economic insecurity, poverty, inequity, regressive tax, pluralism, extremism, gender discrimination, labor hostility, class consciousness and conflict, removal of lifetime employment, and the influx of refugees (Hsieh 2011; Kim 2010; Oh and Arditi 2010; Peng 2011; Shin 2012; Suh 2010; Sung 2010). Many of them are just sources of conflict, which impairs social cohesion (Campbell 2000; Lawler et al. 2009). What is more, consumerism, which accompanies individualization, would disfavor social cohesion (Lawler et al. 2009). Hence, South Korea is under mixed forces to sustain and subvert its social cohesion.

Taiwan has such societal conditions as Confucianism, equality, corporatism, social harmony, and a strong polity to countenance social cohesion or the closeness (Hsieh 2011; Hwang 2000; Lei 1994; Zeigler 1988). These conditions tend to keep conflict down and thus maintain social cohesion (Campbell 2000). Corporatism particularly helps maintain 
Table 1 Factors supposed to affect citizens' feeling close in the four East Asian societies

\begin{tabular}{lllll}
\hline & Hong Kong & Korea & Taiwan & Thailand \\
\hline+ & Economic development & Communitarianism & Confucianism & Buddhism \\
& Confucianism & Corporatism & Health insurance \\
& Corporatism & & \\
- & Inequality individualization & Consumerism & Economic restructuring & Cronyism \\
& & & Economic crisis \\
& & & \\
\hline
\end{tabular}

+ , positive, sustaining effect; - , negative, impeding effect

harmony within and between groups (Chen 2006). Essentially, Taiwan has a cultural mainstay to harmonize the society and champion social cohesion. Moreover, Taiwan experiences increasing sociability (Tsai 2006). This is also favorable to social cohesion there. By contrast, economic restructuring, poverty, healthcare fragmentation would be a force imperiling social cohesion in Taiwan (Huang and $\mathrm{Ku} 2011$; Lu and Hsiao 2003; Wang 2001). Accordingly, conflict would arise from economic insecurity due to restructuring.

Thailand would enjoy social cohesion through such societal conditions as the religious pervasion of Buddhism, and state-sponsored health insurance, social capitalism and social contracting (Glassman 2011; Jongudomkarn and Camfield 2006; Tiwsakul and Hackley 2012). Clearly, religion is traditionally a socially cohesive force (Crow 2002; Fararo and Doreian 1998). Furthermore, institutional arrangements for equality and well-being would forestall conflicts and thus install social cohesion (Campbell 2000). In contrast, social cohesion would suffer due to the societal conditions of crony capitalism, corruption, resource misallocation, disparity, inequality, economic crises, rebellion, and social insecurity in Thailand (Glassman 2011; Hewison 2004, 2005; Jongudomkarn and Camfield 2006). These conditions would be the sources of conflict that tears social cohesion. Hence, Thailand witnesses mixed impacts for and against its social cohesion.

Because of the differential distribution and influence of societal conditions in different societies, a differential in social cohesion or closeness among citizens in the East Asian societies is possible. Nevertheless, the supposed differential is yet uncertain, because of insufficient theory and research. That is, there is not a strong rationale to surmise that Hong Kong is lower than are others in social cohesion. The differential in the closeness, nonetheless, is likely to diminish or even vanish, due to mediation or explanation by personal experiences of the societal conditions. Accordingly, a number of personal characteristics and experiences would be determinants of the closeness and consequences of social change or conditions in the East Asian societies. These characteristics and conditions include work-family conflict, family disbanding, costly medicine, job loss, job insecurity, work injury, victimization, investment loss, job training, employment, social class, income, religious affiliation, marriage, parenthood, education, and age (see Table 2). On the one hand, these factors would affect the closeness, and on the other hand, the factors would differ among the four East Asian societies. Altogether, the four societies would be different in citizens' closeness due to their differences in the personal characteristics and conditions. 
Table 2 Expected characteristics that explain societal differentials in citizens' feeling close

\begin{tabular}{|c|c|c|c|c|}
\hline Characteristic & Resource & $\begin{array}{l}\text { Korea versus } \\
\text { Hong Kong }\end{array}$ & $\begin{array}{l}\text { Taiwan versus } \\
\text { Hong Kong }\end{array}$ & $\begin{array}{l}\text { Thailand versus } \\
\text { Hong Kong }\end{array}$ \\
\hline Age & Surplus & + & + & + \\
\hline Education & Surplus & + & + & - \\
\hline Married & Surplus & + & + & + \\
\hline Parenthood & Surplus & + & + & + \\
\hline Part-time work & Deficit & - & - & - \\
\hline Self-employed & Surplus & + & + & + \\
\hline Retired & Deficit & - & - & - \\
\hline Homemaker & Deficit & + & + & + \\
\hline Student & Deficit & + & + & + \\
\hline Unemployed & Deficit & - & - & - \\
\hline Temporary employment & Deficit & + & + & + \\
\hline Daily employment & Surplus & - & - & - \\
\hline Breadwinner & Surplus & - & - & + \\
\hline Family income & Surplus & - & - & - \\
\hline Social class & Surplus & - & - & - \\
\hline Buddhist versus others & Surplus & + & + & + \\
\hline Christian versus others & Surplus & - & - & - \\
\hline Work-to-family conflict & Deficit & + & + & + \\
\hline Family-to-work conflict & Deficit & + & + & + \\
\hline Family disbanding: oneself & Deficit & + & + & + \\
\hline Family disbanding: family member & Deficit & + & + & + \\
\hline Costly medicine: oneself & Deficit & - & - & + \\
\hline Costly medicine: family member & Deficit & - & - & + \\
\hline Job loss: oneself & Deficit & + & + & + \\
\hline Job loss: family member & Deficit & + & + & + \\
\hline Job insecurity: oneself & Deficit & + & + & + \\
\hline Job insecurity: family member & Deficit & + & + & + \\
\hline Work injury: oneself & Deficit & + & + & - \\
\hline Work injury: family member & Deficit & + & + & - \\
\hline Victimization: oneself & Deficit & - & - & - \\
\hline Victimization: family member & Deficit & - & - & - \\
\hline Investment loss: oneself & Deficit & + & + & - \\
\hline Investment loss: family member & Deficit & + & + & - \\
\hline Job training & Surplus & - & - & - \\
\hline
\end{tabular}

+ , accounting for a positive differential from Hong Kong; -, accounting for a negative differential from Hong Kong

\section{Conflict Explanation}

The simplest explanation for the weakening of social cohesion due to such adverse experiences as work-family conflict, work injury, job insecurity, and unemployment is conflict theory. Accordingly, conflict theory posits that conflict characterizing or arising 
from various noxious experiences is divisive and subversive of social cohesion (Campbell 2000; Lawler et al. 2009). Such experiences tend to disjoin one from others, including organizations, institutions, and even family members. From a broader perspective of social force, each of the experiences exerts a fragmenting force forbidding the citizen from exercising social cohesion or feeling close to fellow citizens. Conflict or social force theory has the advantage that it does not require the citizen to respond rationally, including targeting the source of conflict and maximizing one's interest. First, there is spillover of conflict from one source to another and to fellow citizens in the city generally. This is because of the interrelatedness of different sources and actors in society. Thus, workfamily conflict can spill over to conflict with neighbors and strangers in society. Second, conflict and its perpetuation and propagation can be irrational, in the sense that they are not rewarding materially or concretely. Hence, reducing closeness from fellow citizens would not resolve or compensate for a work-family conflict. An additional consideration, given the spillover of conflict maintained in conflict theory, is that the noxious experiences of one's family members are also likely to restrain one's feeling close to fellow citizens. Therefore, the hypothesis suggests that the noxious experience of one or one's family members weakens one's feeling close to fellow citizens.

Conversely, conflict theory predicts that empowerment or supportive force or resources are conducive to one's social cohesion (Lawler et al. 2009; Thye et al. 2002). On the one hand, the power or support would serve to resolve conflicts, and on the other hand, it drives and attracts people to come and work together, just because everyone has something to benefit others. As such, conditions that enhance one's resources, including family income, marriage, education, age, social class, and job training would raise one's social cohesion or closeness to fellow citizens. The contributions of such characteristics to social cohesion are evident in existing research (Espvall and Dellgren 2008; La Grange 2011; La Grange and Yip 2001; Lee and Robbins 1998; Letki 2008). Hence, conflict theory or its observe of power or social force theory leads to the hypothesis that characteristics or conditions that increase one's resources make one feel close to fellow citizens.

Age, according to conflict or power theory, has already been notable to contribute to feeling close to fellow citizens. In addition, the contribution is also attributable to increased contact and adherence to the traditional norm favoring to social cohesion. Both the contact and norm would be conducive to feeling close with others (Laurence 2011; Sturm 1998; Wilkinson 2009). The support of the societal norm for the age gradient in feeling close is likely to be more salient in Korea and Taiwan, as compared with Hong Kong. This is because of sharp social change there that forges a clear cleavage between older and younger citizens (Huang and Ku 2011; Oh and Arditi 2010).

\section{Contextualizing the Conflict Mechanism in East Asia}

Some of the studies reviewed above have shown or purported the adverse impacts of conflict and the felicitous effects of support, power, or resources on social cohesion in East Asia (Huang and Ku 2011; La Grange 2011; La Grange and Yip 2001; Oh and Arditi 2010). Accordingly, resources available from one and another are conducive to social cohesion and competition for it foments conflict and thus subverts social cohesion. In addition, contextual factors in the Asian societies, notably the familistic, collectivistic, or social orientation, informality, and population density, would warrant the impacts of family, work, and other social conflicts and stresses on social cohesion. In the first place, family, work, social, and personal lives are highly connected in Asia societies (Cohen et al. 
2007; Holliday 2000). Particularly, the family and kinship are central in relatives and influential there. Family-work interface is therefore of remarkable policy concern in East Asian societies (Peng 2011; Wang 2003). At the same time, informal influence rather than formal or state influence is salient in East Asian societies (Kung et al. 2004). Accordingly, East Asians depend considerably on informal networks rather than state provision, and this would bolster interconnections within the networks. The density population or dense living condition in East Asia also sustains channels for conveying influences among family, work, and other social domains among East Asians (Forrest et al. 2002; Jongudomkarn and Camfield 2006). These channels or conditions suffice the possibility that changes in family, work, or social life trigger a change in closeness to fellow citizens. In this regard, East Asians are experiencing the former changes remarkably and differentially (Han and Shim 2010). The latter change or decline is also happening (Yamaoka 2008). Thus, these coexisting changes in the East Asian context are likely to accrue from their linkage at the individual level.

Characteristics in each of the societies furthermore are likely to account for societal differentials in social cohesion or closeness. In the first place, conflict of power theory suggests that each characteristic represents either a surplus or deficit in resources due to empowerment and conflict respectively. A society that has more surpluses would have greater social cohesion, whereas a society that encounters more deficits would manifest lower social cohesion. For instance, when age represents a resource surplus, a society with an older population would have greater social cohesion (see Table 2). Conversely, when being a student indicates a resource deficit, a society having a smaller proportion of students would have higher social cohesion. Another converse case is that when daily employment is a resource surplus, a society having less daily employment would have weaker social cohesion. A further case is that when medical cost represents a resource deficit, a society with higher medical cost would witness lower social cohesion. As such, Korea is likely to hold higher social cohesion when Korea has higher extents of education and marriage, and fewer economic problems (Lew et al. 2011; Peng 2011). Meanwhile, Korea is likely to have lower social cohesion when Korea has higher extents of retirement and unemployment and less work empowerment (Hsieh 2011; Kim 2010). Taiwan is likely to resemble Korea in its characteristics increasing and diminishing social cohesion (Hsieh 2011; Hwang 2000; Wang 2003). Thailand also resembles Korea and Taiwan in many cases, but is likely to sustain higher social cohesion through Buddhist faith and reduced medical cost (Glassman 2011; Jongudomkarn and Camfield 2006; Tiwsakul and Hackley 2012). However, Thailand is likely to have diminished social cohesion due to the economic crisis and deficiency (Hewison 2005; Jongudomkarn and Camfield 2006). Conversely, Hong Kong is likely to sustain higher social cohesion through better economic and employment performance (Delang and Lung 2010; Li et al. 2011). Meanwhile, Hong Kong is likely to witness weaker social cohesion due to greater work conflict or stress (Ma 2011; Sing 2004).

The noxious experiences of work-family conflict, victimization, and others, are more likely to happen in the citizen of Hong Kong than in the citizen in Korea, Taiwan, or Thailand. Some clues for this is present in some existing studies (Cheung and Leung 2011; Yamaoka 2008). That is, stress and illness are higher in the Hong Kong citizen than in those in one in Japan. Moreover, psychoticism is higher in the citizen of Hong Kong than in one of the United States or another Western place (van Hemert et al. 2002). Precisely, work-family conflict is higher in Hong Kong than in the West (Wharton and Blair-Loy 2006). Work conflict is also particularly notable in Hong Kong (Spector et al. 2004). One supplementary instance is the highest casualty of the severe acute respiratory syndrome in 
Hong Kong (Leung and Wong 2005). This would be attributable to work restructuring in Hong Kong (Cheung 2005, 2008; Lang et al. 2001). Moreover, income inequality and relative poverty are the most awful in Hong Kong (Ma et al. 2009; Wong 2011). Such evidence furnishes a basis for the hypothesis that one has more noxious experiences in Hong Kong than in Korea, Taiwan, or Thailand.

Overall, the study expects to find differentials among the East Asian societies in feeling close to fellow citizens before controlling for personal characteristics and experiences. Once with the controlling, the study expects to find trivial differentials among the societies. This would reflect that the personal characteristics and experiences explain the apparent differentials before controlling.

\section{Methods}

\subsection{Participants}

Data were from a survey of 4,087 adult residents in 2009 in four East Asian societies, Hong Kong $(n=681)$, South Korea $(n=1,006)$, Taiwan $(n=1,200)$, and Thailand $(n=1,200)$. In South Korea, Taiwan, or Thailand, about half of the sample was female (50.1-50.4 \%, see Table 3). In contrast, the Hong Kong sample has a higher proportion of women $(61.8 \%)$. The average age of respondents in Korea and Taiwan was between 43 $(S D=14.2)$ and $44(S D=15.8)$ years old. That of respondents in Thailand was 40.2 $(S D=14.4)$, and that in Hong Kong was 35.8 ( $\mathrm{SD}=14.2)$. Respondents in Taiwan had the highest education $(M=13.9$ years, $S D=2.8$ years $)$, and those in Thailand had the lowest education $(M=10.0$ years, $S D=4.3$ years). Korean respondents were mostly married $(69.7 \%)$, whereas those in Hong Kong were least likely married $(45.3 \%)$. Moreover, Korean respondents were mostly parents $(73.4 \%)$, whereas those in Hong Kong were least likely parents $(44.8 \%)$. Whereas $10.9 \%$ of the Hong Kong respondents were part-time workers, only $4.0 \%$ of those in Thailand were part-time workers. About one quarter of the respondents in Korea and Thailand were self-employed, whereas only $1.2 \%$ of those in Hong Kong were self-employed. In the Taiwan sample, $8.1 \%$ were retired, whereas only $1.8 \%$ of those in Thailand were retired. Homemakers accounted for $20.4 \%$ of the Korean sample, whereas they only accounted for $5.7 \%$ of the Thai sample. In contrast, $26.3 \%$ of the Hong Kong respondents were students, whereas only $3.5 \%$ of the Taiwan respondents were students. In the Thai sample, $6.3 \%$ were unemployed, where only $<3.0 \%$ of the respondents in Hong Kong and Korea were unemployed. In Hong Kong, $12.0 \%$ of the respondents were in temporary employment, whereas only $8.2 \%$ of the Taiwan respondents were in temporary employment. In the Thai sample, $13.1 \%$ were in the daily contract form of employment, whereas only $2.4 \%$ of the Korean respondents were such a form. Based on a common scale of family income to reflect the relative position in society (on a $0-100$ scale), the Thai respondents had the highest family income $(M=48.3, S D=17.3)$, whereas those in Taiwan had the lowest $(M=42.5, S D=17.6)$. The social class was highest in the Korean sample $(M=40.8, S D=38.6)$ and lowest in the Thai sample $(M=28.0, S D=21.8)$. In this connection, the scoring for social class assigned a score of 100 to employers, capitalists, or the bourgeoisie had the highest social class, 66.7 to professionals and managers, 33.3 to ordinary workers, and 0 to nonworking people, including homemakers and students. Buddhists accounted for $90.0 \%$ of the Thai sample, whereas they accounted for only $7.4 \%$ in the Hong Kong sample. In contrast, $33.2 \%$ of the Korean respondents were Christians, whereas only $0.4 \%$ of the Thai respondents were Christians. 
Table 3 Means or percentages

\begin{tabular}{|c|c|c|c|c|c|}
\hline Variable & Scoring & Hong Kong & South Korea & Taiwan & Thailand \\
\hline$N$ & & 681 & 1,006 & 1,200 & 1,200 \\
\hline Feeling close to fellow citizens & $0-100$ & 56.1 & 52.0 & 51.8 & 61.3 \\
\hline Female & $0-100$ & 61.8 & 50.4 & 50.3 & 50.1 \\
\hline Age & years & 35.8 & 43.7 & 43.0 & 40.2 \\
\hline Education & years & 12.4 & 13.1 & 13.9 & 10.0 \\
\hline Married & $0-100(\%)$ & 45.3 & 69.7 & 51.6 & 61.4 \\
\hline Parenthood & $0-100(\%)$ & 44.8 & 73.4 & 56.2 & 69.3 \\
\hline Part-time work & $0-100(\%)$ & 10.9 & 7.2 & 8.0 & 4.0 \\
\hline Self-employed & $0-100(\%)$ & 1.2 & 28.2 & 5.1 & 28.4 \\
\hline Retired & $0-100(\%)$ & 2.9 & 3.4 & 8.1 & 1.8 \\
\hline Homemaker & $0-100(\%)$ & 12.8 & 20.4 & 8.0 & 5.7 \\
\hline Student & $0-100(\%)$ & 26.3 & 6.4 & 3.5 & 7.2 \\
\hline Unemployed & $0-100(\%)$ & 2.3 & 2.5 & 3.0 & 6.3 \\
\hline Temporary employment & $0-100(\%)$ & 12.0 & 9.3 & 8.2 & 9.8 \\
\hline Daily employment & $0-100(\%)$ & 5.5 & 2.4 & 3.1 & 13.1 \\
\hline Breadwinner & $0-100(\%)$ & 28.1 & 45.7 & 43.9 & 93.7 \\
\hline Family income & $0-100$ & 44.9 & 46.7 & 42.5 & 48.3 \\
\hline Social class & $0-100(\%)$ & 34.6 & 40.8 & 38.2 & 28.0 \\
\hline Buddhist & $0-100(\%)$ & 7.4 & 19.9 & 34.4 & 90.0 \\
\hline Christian & $0-100(\%)$ & 25.1 & 33.2 & 11.8 & 0.4 \\
\hline Work-to-family conflict & $0-100$ & 36.4 & 27.4 & 35.2 & 20.5 \\
\hline Family-to-work conflict & $0-100$ & 21.4 & 21.4 & 23.4 & 7.3 \\
\hline Family disbanding: oneself & $0-100(\%)$ & 2.5 & 1.0 & 3.1 & 3.2 \\
\hline Family disbanding: family member & $0-100(\%)$ & 8.7 & 2.3 & 2.7 & 2.0 \\
\hline Costly medicine: oneself & $0-100(\%)$ & 3.5 & 6.6 & 1.9 & 5.6 \\
\hline Costly medicine: family member & $0-100(\%)$ & 5.3 & 11.0 & 9.9 & 6.7 \\
\hline Job loss: oneself & $0-100(\%)$ & 4.4 & 3.2 & 6.0 & 3.7 \\
\hline Job loss: family member & $0-100(\%)$ & 6.3 & 3.2 & 7.3 & 3.4 \\
\hline Job insecurity: oneself & $0-100(\%)$ & 6.0 & 2.0 & 8.4 & 2.1 \\
\hline Job insecurity: family member & $0-100(\%)$ & 12.3 & 2.5 & 12.2 & 2.0 \\
\hline Work injury: oneself & $0-100(\%)$ & 3.1 & 0.3 & 3.8 & 8.8 \\
\hline Work injury: family member & $0-100(\%)$ & 2.6 & 0.9 & 3.6 & 6.4 \\
\hline Victimization: oneself & $0-100(\%)$ & 1.5 & 1.5 & 2.2 & 1.7 \\
\hline Victimization: family member & $0-100(\%)$ & 1.6 & 0.7 & 2.4 & 1.9 \\
\hline Investment loss: oneself & $0-100(\%)$ & 10.7 & 7.4 & 10.2 & 16.8 \\
\hline Investment loss: family member & $0-100(\%)$ & 11.6 & 3.6 & 7.1 & 17.6 \\
\hline Job training & $0-100(\%)$ & 22.1 & 8.7 & 29.3 & 9.5 \\
\hline
\end{tabular}

\subsection{Instrument}

These data evolved from the same standard questionnaire, yet using the language of each of the societies (Lin et al. 2013). The standard questionnaire was adapted from the one originally used in Europe (Bohnke 2008). It measured feeling close to fellow citizens, 
work-family conflicts, stressors, and others using a number of question items. In some of the measures, single items were useful (Knecht et al. 2011; Sobolewski and Amato 2007). The translation of the questions engaged the endeavor and endorsement of the international research team to ensure its conceptual and semantic equivalence across the places.

Feeling close to fellow citizens in the city was a single item about the closeness (Sobolewski and Amato 2007). The item employed the scoring such that a score of 100 represented "very close", 66.7 for "close", 33.3 for "distant", and 0 for "very distant". The distribution of the scores resembled a normal distribution (skewness $=-.174$, kurtosis $=-.071$ ), thus making them suitable of regression analysis.

Work-to-family conflict was a mean score of two items about what happened during the year before the survey (Drobnic et al. 2010): I have come home from work too tired to do some of the household jobs which need to be done; It has been difficult for me to fulfill my family responsibilities because of the amount of time spent on the job. Each item took a rating on a five-point scale running from "never" to "several times a week". The scoring assigned 100 to "several times a week", 75 to "several times a month", 50 to "several times a year", 25 to "less often or rarely", and 0 to "never (including no job and thus no conflict)". Internal consistency reliability was .840 for the two-item measure used in the four East Asian societies.

Family-to-work conflict was a single-item measure, which read, "I have found it difficult to concentrate at work because of my family responsibilities" (Knecht et al. 2011). It referred to conflict experienced in the year preceding the survey (Drobnic et al. 2010). The rating scale and scoring was the same as those for work-to-family conflict.

Stressors included family disbanding, costly medical care, job loss, job insecurity, work injury, criminal victimization, and investment loss encountered in the year preceding the survey. Each of them had one item referring to the respondent's own experience with the stressor and another one referring to family members' experience. Altogether, they generated 14 dichotomous variables, each having a score of 0 for "absence" and a score of 100 for "presence".

Job training was a single-item referring to the reception of the training in the year preceding the survey. It was a dichotomous variable having a score of 0 for "absence" and a score of 100 for "presence".

Acquiescence or denial was a control variable used in regression analysis to minimize the bias of the common self-report (Zagorski 1999). It referred to tendency to rate every items highly, regardless of item meaning. Its score was the average of the standardized scores of all items included in the questionnaire. A higher score indicated a higher tendency of denial, disagreeing or trivializing everything.

Interactions between age and society were the product of the standardized scores of age and society indicators. The computation served to minimized multicollinearity present in regression analysis that involved the interactions and their constituents.

\subsection{Procedure}

In South Korea, Taiwan, and Thailand, a random sampling procedure started with a stratified random selection of residential addresses in Seoul, Taipei, and Bangkok and then a random selection of adults (aged 18 years or older) for face-to-face survey interviews. The strata were 12 districts identified in each of the cities. In the random selection of respondents in the addresses, the sampling procedure selected male and female respondents in proportion to the city population. Meanwhile in Hong Kong, telephone survey interviews obtained data from residents recruited through referral by the students of some 
universities in the city. Specifically, a quota sampling procedure recruited residents of different categories of age and gender combinations in proportion to the adult population in Hong Kong. Trained interviewers performed the face-to-face or telephone interviews. The smallest sample size in Hong Kong $(n=681)$ was sufficient to endorse a weak effect size of .107 or greater with confidence of $95 \%$ and statistical power of $80 \%$. Under the same conditions, the whole sample of 4,087 was sufficient to endorse a very weak effect size of .044 .

Data analysis started with a confirmatory factor analysis of attitudinal measures and proceeded with a series of regression analysis of feeling close to fellow citizens (using Mplus, Muthen and Muthen 2006). The confirmatory analysis served to verify the factorial validity of the attitudinal measures of feeling close and differences among the East Asian societies, family-to-work conflict, and work-to-family conflict. It identified the three separate factors for the measures and distinguished them from a method factor representing the rating or acquiescence common to all the items (Podsakoff et al. 2003). With the verification of the validity, the linear regression analysis of feeling close proceeded in four steps with forced entry (using the enter option in regression analysis in SPSS 20). The first step was to reveal differentials in the closeness relative to Hong Kong. This step comprised three alternatives to generate six paired comparisons, with each society served as the reference category alternately. Then, the second step introduced personal characteristics as predictors, the third step introduced personal and family experiences, and the fourth step introduced interactions between age and Korea and Taiwan. This series of analyses elucidated how personal characteristics and experiences explained the differentials found in the first step. In addition, another series of linear regression analysis revealed differences among the four societies, with Hong Kong held as the reference society.

\section{Results}

Feeling close to fellow citizens was at a modest level in all the four East Asian societies $(M=51.8-61.3, S D=20.5-23.2$, see Table 3). Among the societies, Thailand exhibited the highest closeness and Taiwan scored the lowest. Work-to-family conflict and family-towork conflict were rather low in the four societies $(M=7.3-36.4, S D=17.7-30.4)$. Family-to-work conflict was lowest in Thailand $(M=7.3, S D=17.7)$. In contrast, Hong Kong and Taiwan had the highest work-to-family conflict $(M=36.4$ and 35.2, $S D=25.6-35.4)$. Job training was highest in Taiwan (29.3\%), whereas it was lowest in South Korea and Thailand (8.7 and $9.5 \%$ ). Noxious experiences were all very low, and the lowest was work injury in South Korea $(0.3 \%)$.

Confirmatory factor analysis verified the factorial validity of the attitudinal measures of feeling close to fellow citizens and work-family conflicts. Accordingly, the items identified their respective trait factors, independent of the method factor (see Table 4). Notably, loadings on the method factors were low, demonstrating discriminant validity as a component of factorial validity. The factorial validity was furthermore justified by the goodness-of-fit of the whole confirmatory-factor model $\left[L^{2}(1)=1.061, p=.303\right.$, $C F I=1.000$, SRMR $=.002$, RMSEA $=.003]$.

The four steps of linear regression analysis furnished a moderate explanation for feeling close to fellow citizens $\left(R^{2}=.137\right.$, Gomez-Benito et al. 2009). The first step of linear regression analysis revealed that Korea and Taiwan had the closeness significantly lower than that in Hong Kong ( $\beta=-.105$ and -.118 , see Table 5). In contrast, Thailand displayed the closeness that was significantly higher than that in Hong Kong $(\beta=.071)$. 
Table 4 Standardized factor loadings

\begin{tabular}{|c|c|c|c|c|}
\hline \multirow[t]{2}{*}{ Item } & \multicolumn{3}{|c|}{ Trait factor } & \multirow{2}{*}{$\begin{array}{l}\text { Method } \\
\text { factor }\end{array}$} \\
\hline & Closeness & $\begin{array}{l}\text { Family-to- } \\
\text { work conflict }\end{array}$ & $\begin{array}{l}\text { Work-to- } \\
\text { family conflict }\end{array}$ & \\
\hline $\begin{array}{l}\text { Feeling close to fellow } \\
\text { citizens }\end{array}$ & .966 & & & -.259 \\
\hline $\begin{array}{l}\text { Difficult to concentrate at } \\
\text { work }\end{array}$ & & 1.000 & & -.024 \\
\hline Coming home too tired & & & .824 & -.017 \\
\hline Difficult to full responsibility & & & .938 & -.011 \\
\hline
\end{tabular}

Alternatively, the closeness was significantly lower in Taiwan than in Korea and significantly higher in Thailand than in Korea $(\beta=-.088$ and .100). Furthermore, the closeness was significantly higher in Thailand than in Taiwan $(\beta=.107)$. This step thus manifested significant differentials in the closeness relative to Hong Kong.

The second step of regression analysis introduced personal characteristics for the prediction of the closeness. Among the characteristics, age, being married, being a student, daily employment, and family income exhibited significant positive effects on the closeness, whereas education and acquiescence indicated significant negative effects. With the controlling for the personal characteristics, the societal differentials in the closeness dropped precipitously. Importantly, the differentials of Taiwan and Thailand, relative to Hong Kong, were no longer significant $(\beta=-.026$ and .025 , see Table 5). While the differentials of Korea remained statistically significantly, it greatly reduced $(\beta=-.041)$. Other significant differentials were that between Thailand and Korea and between Thailand and Taiwan $(\beta=.057$ and .048). Therefore, personal characteristics already explained a great deal of the differentials.

The third step of regression analysis added personal and family experiences as the predictors of the closeness. Among the experiences, work-to-family conflict, family-to-work conflict, and costly medicine displayed very weak but statistically significant negative effects on the closeness. With the controlling for these experiences, the differentials of Taiwan and Thailand almost evaporated $(\beta=-.016$ and -.002 , see Table 5). The differential of Korea further dwindled, albeit remaining statistically significant $(\beta=-.039)$. Another remaining significant differential happened between Thailand and Korea $(\beta=.045)$.

The fourth step of regression analysis of the closeness added the two interaction terms, both of which showed significant positive effects $(\beta=.069$ and .053 , see Table 5). These effects meant that age had a more positive effect in Korea and Taiwan, relative to that in Hong Kong. They were supportive of the hypothesis.

Another series of regression analyses showed pervasive differentials in personal characteristics and experiences among the East Asian societies. Essentially, only the experiences of one's job loss and victimization, and victimization happening to family members did not exhibited significant differentials relative to Hong Kong. Among the significant differentials, the strongest revealed that Taiwan and South Korea had lower proportions of students $(\beta=-.362$ and -.295 , see Table 6$)$, and Thailand had lower work-to-family conflict, family-to-work conflict, and education $(\beta=-.312,-.318$, and -.280$)$, and a higher proportion of Buddhists and breadwinners $(\beta=.685$ and .466$)$.

Importantly, personal characteristics and experiences that mediated the societal differentials in the closeness were denial, age, education, family income, daily employment, 
Table 5 Standardized effects on feeling close to fellow citizens

\begin{tabular}{|c|c|c|c|c|}
\hline Predictor & (1) & (2) & (3) & (4) \\
\hline Korea versus Hong Kong & $-.105 * * *$ & $-.041^{*}$ & $-.039 *$ & $-.039 *$ \\
\hline Taiwan versus Hong Kong & $-.118 * * *$ & -.026 & -.016 & -.015 \\
\hline Thailand versus Hong Kong & $.071 * * *$ & .025 & -.002 & -.006 \\
\hline Taiwan versus Korea & $-.088 * * *$ & -.007 & .004 & .002 \\
\hline Thailand versus Korea & $.100 * * *$ & $.057 * *$ & $.045 *$ & -.006 \\
\hline Thailand versus Taiwan & $.107 * * *$ & $.048^{*}$ & .034 & .000 \\
\hline Female versus male & - & -.011 & -.011 & -.011 \\
\hline Age & - & $.089 * * *$ & $.067 * *$ & $.083 * * *$ \\
\hline Education & - & $-.098 * * *$ & $-.096 * * *$ & $-.092 * * *$ \\
\hline Married & - & $.059^{* *}$ & $.062 * *$ & $.058 * *$ \\
\hline Parenthood & - & -.012 & -.010 & -.020 \\
\hline Part-time work & - & -.013 & -.013 & -.010 \\
\hline Self-employed & - & .016 & .026 & .025 \\
\hline Homemaker & - & -.038 & $-.054 *$ & $-.064 * *$ \\
\hline Student & - & $.041 *$ & .028 & .014 \\
\hline Unemployed & - & -.030 & -.031 & -.032 \\
\hline Temporary employment & - & .000 & .010 & .007 \\
\hline Daily employment & - & $.050 * *$ & $.059 * *$ & $.054 * *$ \\
\hline Family income & - & $.087 * * *$ & $.079 * * *$ & $.084 * * *$ \\
\hline Social class & - & -.042 & -.018 & -.028 \\
\hline Buddhist versus others & - & .016 & .020 & .016 \\
\hline Christian versus others & - & .013 & .002 & .004 \\
\hline Denial & - & $-.243 * * *$ & $-.251 * * *$ & $-.248 * * *$ \\
\hline Work-to-family conflict & - & - & $-.047 *$ & $-.049 *$ \\
\hline Family-to-work conflict & - & - & $-.055^{*}$ & $-.053 *$ \\
\hline Family disbanding: oneself & - & - & -.007 & -.010 \\
\hline Family disbanding: family member & - & - & .028 & .030 \\
\hline Costly medicine: oneself & - & - & $-.040 *$ & $-.039 *$ \\
\hline Costly medicine: family member & - & - & $-.041 *$ & $-.039 *$ \\
\hline Job loss: oneself & - & - & .005 & .001 \\
\hline Job loss: family member & - & - & .013 & .012 \\
\hline Job insecurity: oneself & - & - & -.011 & -.010 \\
\hline Job insecurity: family member & - & - & -.020 & -.019 \\
\hline Work injury: oneself & - & - & .003 & .004 \\
\hline Work injury: family member & - & - & .015 & .013 \\
\hline Victimization: oneself & - & - & -.014 & -.012 \\
\hline Victimization: family member & - & - & -.005 & -.006 \\
\hline Investment loss: oneself & - & - & .008 & .007 \\
\hline Investment loss: family member & - & - & -.013 & -.015 \\
\hline Job training & - & - & -.024 & -.022 \\
\hline Korea $\times$ age & - & - & - & $.053 * *$ \\
\hline Taiwan $\times$ age & - & - & - & $.069 * * *$ \\
\hline$R^{2}$ & .032 & .119 & .131 & .137 \\
\hline$\Delta R^{2}$ & & $.087^{* * * *}$ & $.012 *$ & $.006^{*}$ \\
\hline
\end{tabular}

$* p<.05, * * p<.01, * * * p<.001$ 
student status, married status, work-family conflict, and costly medicine. First, as the Korean and Taiwanese respondents showed higher denial of everything, relative to Hong Kong, they scored lower on feeling close to fellow citizens. Conversely, the Thai respondent exhibited lower denial, and thus scored higher on feeling close. Second, the Thai respondent was older and age had a positive effect on the closeness, and thus the Thai respondent displayed higher closeness to fellow citizens. Third, the Korean and Taiwanese respondents had higher education and education had a negative effect on the closeness, and thus the respondents showed lower closeness to fellow citizens. Conversely, the Thai respondent had lower education and thus higher closeness to fellow citizens. Fourth, the Taiwan respondent had lower relative family income and family income had a positive effect on the closeness, and thus the respondent was lower in the closeness. Conversely, the Thai respondent had higher relative family income and thus was higher in the closeness. Fifth, the Korean and Taiwan respondents were less likely in daily contract employment and this employment displayed a positive effect on the closeness, and thus the respondents were lower in the closeness. Conversely, the Thai respondent was more likely in daily contract employment and thus higher in the closeness. Sixth, the Korean and Taiwanese respondents were composed of fewer students and the student was lower in feeling close to fellow citizens, and thus the respondents were lower in the closeness. Seventh, the Thai respondent was more likely married and this status was conducive to feeling close to fellow citizens, and thus the respondent was higher in the closeness. Eighth, the Thai respondent was lower in both family-to-work conflict and work-to-family conflict and the conflicts would reduce the closeness, and thus the respondent fared higher in the closeness. Ninth, the Korean and Taiwanese respondents were more likely to experience costly medicine and the experience was detrimental to the closeness, and thus the respondents scored lower on the closeness.

\section{Discussion}

Differentials in feeling close to fellow citizens appear in South Korea, Taiwan, and Thailand relative to Hong Kong. As such, Thailand shows the highest closeness among its citizens, Hong Kong is the next highest, and Korea and Taiwan are lower, given that the average closeness is at a modest level for all the four East Asian societies $(M=51.8-61.3)$. Nonetheless, the differentials vanish or at least become trivial after controlling for personal characteristics and experiences. This means that personal characteristics and experiences explain the differentials largely. The personal characteristics and experiences are in turn partly products or manifestations of societal conditions of the East Asian societies. In this way, the society affects citizens' closeness through influences on personal characteristics and experiences. Essentially, the nine such characteristics and experiences identified are denial, age, education, family income, daily contract employment, student status, marital status, work-family conflict, and costly medicine. Among them, education, student status, marital status, daily contract employment, work-family conflict, and costly medicine are more likely than are others to be susceptible to societal disposition. Accordingly, a society that keeps more citizens in school, marriage, and daily contract employment would sustain more closeness among citizens. The contributions of these factors would hinge on the empowerment maintained in power, conflict, or social force theory. In this case, the empowerment springs from school and marriage, in the form of social support that facilitates social contact and thereby cohesion or closeness. Such social support, contact, and empowerment have shown their contributions to social 
Table 6 Standardized effects of societies

\begin{tabular}{|c|c|c|c|}
\hline Predictor & $\begin{array}{l}\text { Korea versus } \\
\text { Hong Kong }\end{array}$ & $\begin{array}{l}\text { Taiwan versus } \\
\text { Hong Kong }\end{array}$ & $\begin{array}{l}\text { Thailand versus } \\
\text { Hong Kong }\end{array}$ \\
\hline Female versus male & $-.085^{* * *}$ & $-.092 * * *$ & $-.093 * * *$ \\
\hline Age & $.212 * * *$ & $.207 * * *$ & $.136 * * *$ \\
\hline Education & $.082 * * *$ & $.187 * * *$ & $-.280 * * *$ \\
\hline Married & $.186^{* * *}$ & $.052 * *$ & $.131 * * *$ \\
\hline Parenthood & $.236 * * *$ & $.104 * * *$ & $.217 * * *$ \\
\hline Part-time work & $-.047^{*}$ & $-.039 *$ & $-.093 * * *$ \\
\hline Self-employed & $.274 * * *$ & $.042 *$ & $.296 * * *$ \\
\hline Retired & .006 & $.071 * * *$ & -.016 \\
\hline Homemaker & $.089 * * *$ & $-.060 * *$ & $-.089 * * *$ \\
\hline Student & $-.295 * * *$ & $-.362 * * *$ & $-.304 * * *$ \\
\hline Unemployed & .003 & .015 & $.089 * * *$ \\
\hline Temporary employment & $-.107 * * *$ & $-.136^{* * *}$ & $-.118 * * *$ \\
\hline Daily employment & $-.075 * * *$ & $-.082 * *$ & $.116^{* * *}$ \\
\hline Breadwinner & $-.033 *$ & $-.053 * * *$ & $.466^{* * *}$ \\
\hline Family income & $.034 *$ & $-.088 * * *$ & $.084 * * *$ \\
\hline Social class & $-.044 *$ & $-.089 * * *$ & $-.242 * * *$ \\
\hline Buddhist versus others & $.085^{* * *}$ & $.222 * * *$ & $.685 * * *$ \\
\hline Christian versus others & $.075 * * *$ & $-.133 * * *$ & $-.245^{* * *}$ \\
\hline Denial & $.128 * * *$ & $.118 * * *$ & $-.100 * * *$ \\
\hline Work-to-family conflict & $-.204 * * *$ & $-.115^{* * *}$ & $-.312 * * *$ \\
\hline Family-to-work conflict & $-.072 * * *$ & $-.043 *$ & $-.318 * * *$ \\
\hline Family disbanding: oneself & $-.043 *$ & .014 & .018 \\
\hline Family disbanding: family member & $-.151 * * *$ & $-.153 * * *$ & $-.169 * * *$ \\
\hline Costly medicine: oneself & $.053 * *$ & -.037 & .037 \\
\hline Costly medicine: family member & $.070 * * *$ & $.059 * *$ & .014 \\
\hline Job loss: oneself & -.027 & .029 & -.019 \\
\hline Job loss: family member & $-.063 * *$ & .015 & $-.063 * *$ \\
\hline Job insecurity: oneself & $-.084 * * *$ & $.047 *$ & $-.088 * * *$ \\
\hline Job insecurity: family member & $-.168 * * *$ & -.009 & $-.188 * * *$ \\
\hline Work injury: oneself & $-.062 * *$ & .012 & $.128 * * *$ \\
\hline Work injury: family member & $-.043^{*}$ & .020 & $.089 * * *$ \\
\hline Victimization: oneself & .000 & .026 & .006 \\
\hline Victimization: family member & -.034 & .027 & .007 \\
\hline Investment loss: oneself & $-.049 * *$ & -.014 & $.079 * * *$ \\
\hline Investment loss: family member & $-.121 * * *$ & $-.075 * * *$ & $.086^{* * *}$ \\
\hline Job training & $-.132 * * *$ & $.083 * * *$ & $-.131 * * *$ \\
\hline
\end{tabular}

$* p<.05, * * p<.01, * * * p<.001$

cohesion in existing research (Lee and Robbins 1998; Rossi 2001; Vasi and Macy 2003). Because of their contributions, schooling and marriage are conducive to social cohesion, in view of extant evidence (Espvall and Dellgren 2008; Wilson 2000). By contrast, a society that raises citizens' education, the cost in medicine, and work-family conflict would reduce 
closeness among citizens. Costly medicine and work-family conflict are very likely the source of tension that constrains the citizen's social cohesion or closeness to others, in light of conflict theory (Campbell 2000; Lawler et al. 2009). Conflict, either intrapersonal or intrapersonal, has appeared to impede social cohesion (Amato and Chendle 2005; Farmer and Fedor 2001). Herein, conflict would drain one's resources, power, and passion for any activity, including social cohesion.

Nevertheless, some unexpected or seemingly anomalous findings deserve attention and deliberation. From the above, daily contract employment appears to be favorable to citizen closeness, whereas education tends to discourage the closeness. These findings, nevertheless, can still be accountable by conflict theory. First, daily contract employment may represent empowerment to enhance the worker's closeness to fellow citizens, as the employment would provide more freedom for the worker to work with different people. This is because daily contract employment would release or require the worker to work in different places or contexts. Working or contact with different people appears to be a basis for social cohesion, according to existing research (Schmid et al. 2009; Wilson and Musick 1999). Second, education would empower the individual's personal efficacy and autonomy, and thus relax his or her reliance on or remaining close to others. Strengthening of individual competence and independence by education is a resounding research finding (Fjellvang 2011; Ohmer 2007). Moreover, individual competence, independence, or autonomy has proven to relieve reliance on or closeness to others (Kalish 2008; Markus 2001). Thus, the empowerment of education would particularly loosen the individual's closeness to fellow citizens. This is a special application of conflict or power theory to the impact of education on social cohesion such that personal empowerment would diminish social cohesion. In contrast, empowerment or social support from marriage and school would increase the person's closeness to others. The divergent impacts may be because social support would keep one inside the social sphere, whereas education or knowledge enhancement would not depend on a social sphere. Therefore, a condition for the socially cohesive impact of empowerment would be social engagement involved in the empowerment. In this sense, the socially cohesive impacts of age and family income are also likely to benefit from social engagement involved in age and family income. Accordingly, age facilitates socialization and adaptation to the social circle, as evidenced in existing research (Keyes and Shapiro 2004; Ulbig 2002). The benefit of age also depends on the social context, such as that of Korea and Taiwan. In this connection, age would be more conducive to closeness to fellow citizens in Korea and Taiwan, probably because age increases respect from other people in the two societies. That is, the Confucian basis of the two societies helps maintain societal respect for older people (Levande et al. 2000; Lin and Yi 2011). The societal respect is a form of social support or resources stemming from the social domain. Moreover, family income obviously is socially relevant, as it arises from and becomes beneficial through a family.

Not all noxious experiences appear to dampen the individual's closeness to fellow citizens. Only the experiences of work-family conflict and costly medicine exhibit such dampening effects. Both effects are consistent with existing research findings about the adverse effects of the conflict (Cnaan and Cascio 1999; Hundley 2001). Notably, both personal and family experiences of costly medicine displayed adverse effects. It appears that the costly medicine would foment a tension plaguing the whole family. Characteristic of such experiences is that they involve multiple systems, work, family, medicine, and even government and the financial institution, which are involved in the costing of medicine. This multiplicity would magnify the conflict and make it socially disintegrating. 
An individual closeness to fellow citizens also did not depend on the individual's religious faith, including Buddhism, Christianity, and others. This finding does not concur with existing findings about the Protestant's greater social cohesion and the positive effect of religious attendance (Ravanera et al. 2003; Tolsma et al. 2009). The present finding, in light of conflict theory, suggests that religion can breed conflict and thus impair social cohesion (Davidson 2008). Accordingly, religion creates a difference in entrenching interests and an identity that are competing and even antagonistic. What is more, the religious conflict looms large due to the large number of religious fellows, who consolidate the difference and a drive for the conflict. These religious factors fulfill the doctrines of conflict theory about gathering power for fueling conflicts.

In conclusion, the four East Asian societies differ in their citizens' social cohesion in terms of feeling close to fellow citizens. Moreover, the differentials in social cohesion are explicable by differentials in resources, or their surpluses or deficits due to conflicts in work, family, and other aspects of social life. Some of the conflicts are attributable to individualization, economic restructuring, and economic crises, which foment job loss and insecurity, work-family conflicts, family disbanding, and victimization (Chang et al. 2009; Jung and Cheon 2006; Kim 2004). In particular, individualization possibly wields its impact through education to discourage social cohesion (Lawler et al. 2009). Conversely, economic development, through its contributions to employment and income, is likely to stabilize social cohesion (Janmaat 2011). What is more, Confucianism and corporatism are likely to stabilize the family and employment and thus bolster social cohesion (Fukuyama 2001; Sturm 1998). Public health insurance, particularly, lowers citizens' medical cost and thereby safeguards their social cohesion. Nevertheless, Buddhism and other religions do not appear to be cohesive factors in the East Asian societies.

\subsection{Further Research}

As this study is not flawless in its design, sampling, and measurement, further research is imperative to substantiate the present findings. The flaw in the design rests on the one-shot, cross-sectional correlational approach, which is limited in its ascertaining of temporal or causal order between experiences and feelings. Although the experiences refer to those happening in the preceding year, they might not certainly precede the feeling of closeness to fellow citizens, because this feeling might have crystallized earlier than the experiences and even some socioeconomic conditions or statuses. Hence, the closeness might have shaped the experience of work-family conflict and employment status. This is possible because existing research has shown that interpersonal relationship or closeness can affect work-family conflict and access to employment (Grzywacz and Marks 2000; Kinnunen and Mauno 1998; Sanchez 2007). Moreover, the design cannot eradicate all significant confounding factors, as it does not run in a controlled, experimental manner. The sampling is also not free of bias, as it does not qualify as probability sampling everywhere to secure representative samples of citizens in the East Asian societies. Such inadequacy would discount the efficiency of statistical analysis employed. Another flaw is the self-report measurement, which is unable to generate fully objective data. Accordingly, personal idiosyncrasies in self-report would affect the measured data in some uncertain ways, which again would attenuate the efficiency of analysis. Apart from this bias, the validity and meaning of self-report measurement are vulnerable to alternative interpretation.

Even though conflict theory provides a viable explanation for various influences on feeling close to fellow citizens, the theory itself has not undergone a rigorous investigation in the study. Further research is indispensable to scrutinizing the application of the theory 
to the closeness. Essential in the conflict or social force theory is conflict or social force that impinges on an individual and thus drives, impedes, or shapes the individual's closeness to others. For one, elaboration of work-family conflict is necessary to unravel its impact on the individual to demoralize and estrange the individual from others. One mediating path would involve stress or strain experienced from the conflict, which in turn retards one's capability and activity, including contact with or closeness to others. Such stress or strain has appeared to detract social cohesion (Garcia and Herrero 2004; Jackson et al. 2006). As noted before, one condition for the estranging effect of conflict or the empowering effect of support is social engagement. Hence, social support, or input from or involving other people is likely to enhance the closeness. Family income is such an input that offers a socially cohesive effect. In contrast, education that empower the individually personally would enable the individual to subsist independently of others. Another instance is the augmentation of the societal norm, such as that favoring respect for older people, of the contribution of age to the closeness. That is, age tends to sustain the closeness more intensely in Korea and Taiwan, relative to Hong Kong and Thailand. All these ramifications of the social engagement condition are crucially in need of further research, in order to illuminate its moderating effect explicitly.

\subsection{Implications}

Given that closeness to fellow citizens is a way of social cohesion that many modern states strive to promote (Hulse and Stone 2007; Mason 2010), shaping societal conditions and thus personal experiences conducive to the closeness represents a vital strategy for the promotion. The promotion is also vital as a balance with individualization thiat accentuates personal rights and thus inadvertently distracts social cohesion (Lawler et al. 2009; O'Hara 2011). In this regard, education, schooling, marital status, work-family conflict, medical expense, and more generally conflict and empowerment are clues to orchestrate the promotion. What the education factor implies is that the promotion of closeness among citizens would need an education that is favorable to the closeness. As such, education that empowers a person individually and separates the person from others would contradict the promotion. Erasing such contradiction is necessary in the reform of education. In contrast, schooling would be a socially supportive factor congenial with the promotion of citizens' closeness. Facilitating not only children but also adult citizens to study together would realize the socially supportive contribution to the promotion. Such education-related implications are consistent with the emphasis of policy on education for the promotion of social cohesion (Green et al. 2003). Another means of the promotion is the encouragement of marriage in order to generalize marital trust to mutual trust among citizens. This means is consistent with policy for family creation (Bogenschneider 2002). Work-family conflict, in contrast, would need elimination or relief in order to prop the promotion for citizens' closeness. Some family-friendly policies would be felicitous to reduction in the conflict (McManus et al. 2003). Essentially, many measures, such as those involving support and demand, are available for the work organization to diminish or relieve the conflict (Allan et al. 2007; Bakker and Geurts 2004). As regards medical expense, making it less costly to citizens is the strategy to promote their mutual closeness. Certainly, medical expense is amenable to state intervention, financing, or subsidization (Mocan et al. 2003). Such intervention effectively keeps medical expense less costly in Hong Kong and Thailand than in Korea and Taiwan (Hewison 2004, 2005; Jongudomkarn and Camfield 2006; Ramesh 2003). Generally, conflict reduction and social empowerment, which enhances resources for and from social engagement, are means to promote citizens' closeness as well as 
personal and social rights. The means are thus judicious to the balanced promotion of citizens' rights and cohesion (Jenson 2003).

Acknowledgments The paper evolves from a research Grant by the Department of Applied Social Studies, City University of Hong Kong.

\section{References}

Allan, C., Loudoun, R., \& Peetz, D. (2007). Influences on work/non-work conflict. Journal of Sociology, 43, 219-239.

Amato, P. R., \& Chendle, J. (2005). The long reach of divorce: Divorce and child well-being across three generations. Journal of Marriage and Family, 67, 191-206.

Bakker, A. B., \& Geurts, S. A. E. (2004). Toward a dual-process model of work-home interference. Work and Occupations, 31, 345-366.

Bell, D. C. (2009). Constructing social theory. Lanham, MD: Rowman \& Littlefield.

Bogenschneider, K. (2002). Family policy matters: How policymaking affects families and what professionals can do. Mahwah, NJ: Lawrence Erlbaum.

Bohnke, P. (2008). Does society matter? Life satisfaction in the enlarged Europe. Social Indicators Research, 87, 189-210.

Brannen, C., Emberty, D. J., \& McGrath, P. (2009). Stress in rural Canada: A structural review of context, stress levels, and sources of stress. Health and Place, 15, 219-227.

Campbell, C. D. (2000). Social structure, space, and sentiment: Searching for common ground in sociological conception of community. Research in Community Sociology, 10, 21-57.

Cartier, C. (2008). Culture and the city: Hong Kong, 1997-2007. China Review, 8, 59-83.

Castells, M. (2000). The rise of the network society (2nd ed.). Oxford, UK: Blackwell.

Chan, R. K. H. (2004). Globalisation, unemployment and the welfare regime in Hong Kong. Social Policy and Society, 3, 273-282.

Chang, S. S., Gynnell, D., Sterne, J. A. C., Lu, T. H., \& Cheng, A. T. A. (2009). Was the economic crisis 1997-1998 responsible for rising suicide rates in East/Southeast Asia? A time trend analysis for Japan, Hong Kong, South Korea, Taiwan, Singapore and Thailand. Social Science and Medicine, 68, $1322-1331$.

Chen, C. (2006). Does the completeness of a household-based convoy matter in intergenerational support exchanges? Social Indicators Research, 79, 117-142.

Cheong, P. H., Edwards, R., Goulbourne, H., \& Solomosm, J. (2007). Immigration, social cohesion and social capital: A critical review. Critical Social Policy, 27, 24-49.

Cheung, C. K. (2005). Rational or demoralized responses to work restructuring in Hong Kong? Human Relations, 58, 223-247.

Cheung, C. K. (2008). Lagged harm of work restructuring and work alienation to work commitment. International Journal of Employment Studies, 16, 170-207.

Cheung, C. K., \& Leung, K. K. (2011). Neighborhood homogeneity and cohesion in sustainable community development. Habitat International, 35, 564-572.

Cnaan, R. A., \& Cascio, T. A. (1999). Performance and commitment: Issues in management of volunteers in human service organization. Administration in Social Work, 24(3/4), 1-38.

Cohen, D., Hoshino-Browne, E., \& Leung, A. K. Y. (2007). Culture and the structure of personal experience: Insider and outsider phenomenologies of the self and social world. Advances in Experimental Social Psychology, 39, 1-67.

Collins, R. (2004). Interaction ritual chains. Princeton, NJ: Princeton University Press.

Constantino, M. J., Wilson, K. R., Horowitz, L. M., \& Pinel, E. C. (2006). The direct and stress-buffering effects of self-organization on psychological adjustment. Journal of Social and Clinical Psychology, $25,333-360$.

Crow, G. (2002). Social solidarities: theories, identities and social change. Buckingham, UK: Open University Press.

Davidson, J. D. (2008). Religious stratification: Its origins, persistence, and consequences. Sociology of Religion, 69, 371-395.

Dayton-Johnson, J. (2003). Knitted warmth: The simple analytics of social cohesion. Journal of SocioEconomics, 32, 623-645.

DeGolyer, M. E. (2001). Conditional citizenship: Hong Kong people's attitudes toward the new motherland. Citizenship Studies, 5, 165-183. 
Delang, C. O., \& Lung, H. C. (2010). Public housing and poverty concentration in urban neighbourhoods: The case of Hong Kong in the 1990s. Urban Studies, 47, 1391-1413.

Diewald, M., \& Ludicke, J. (2006). Community lost or freedom gained? Chantes of social networks after 1989. In M. Diewald, A. Goedicke, \& K. U. Mayer (Eds.), After the fall of the wall: Life courses in the transformation of East Germany (pp. 191-213). Stanford, CA: Stanford University Press.

Drobnic, S., Beham, B., \& Prag, P. (2010). Good job, good life? Working conditions and quality of life in Europe. Social Indicators Research, 99, 205-225.

Espvall, M., \& Dellgren, P. (2008). Can we count on each other? Reciprocity and conflicts in financial support in Sweden. International Journal of Social Welfare, 19, 84-94.

Estes, R. J. (2002). Toward a social development index of Hong Kong: The process of community engagement. Social Indicators Research, 58, 313-341.

Extremera, N., Duran, A., \& Rey, L. (2007). Perceived emotional intelligence and dispositional optimismpessimism: Analyzing their roles in predicting psychological adjustment among adolescents. Personality and Individual Differences, 42, 1069-1079.

Fararo, T. J., \& Doreian, P. (1998). The theory of solidarity: An agenda of problems. In P. Doreian \& T. Fararo (Eds.), The problems of solidarity: Theories and models (pp. 1-31). Australia: Gordon \& Breach.

Fararo, T. J., \& Skvoretz, J. (2002). Theoretical integration and generative structuralism. In J. Berger \& M. Zelditch Jr (Eds.), New directions in contemporary sociological theory (pp. 295-316). Lanham, MY: Rowman \& Littlefield.

Farmer, S. M., \& Fedor, D. B. (2001). Changing the focus on volunteering: An investigation of volunteers multiple contributions to a charitable organization. Journal of Management, 27, 191-211.

Fjellvang, T. (2011). Socialization values, cultural-religious zones and modernization theory. European Sociological Review, 27, 196-211.

Forrest, R., \& Kearns, A. (2001). Social cohesion, social capital and the neighborhood. Urban Studies, 38, $2125-2143$.

Forrest, R., La Grange, A., \& Yip, N. M. (2002). Neighborhood in a high rise, high density city: Some observations on contemporary Hong Kong. Sociological Review, 50, 215-240.

Fukuyama, F. (2001). Social capital, civil society, and development. Third World Quarterly, 22, 7-20.

Garcia, E., \& Herrero, J. (2004). Determinants of social integration in the community: An exploratory analysis of personal, interpersonal and situational variables. Journal of Community and Applied Social Psychology, 14, 1-15.

Glassman, J. (2011). Cracking hegemony in Thailand: Gramsci, Bourdieu and the dialectics of rebellion. Journal of Contemporary Asia, 41, 25-46.

Gomez-Benito, J., Hidalgo, M. D., \& Padilla, J. L. (2009). Efficacy of effect size measures in logistic regression: An application for detecting DIF. Methodology, 5, 18-25.

Green, A., Preston, J., \& Sabutes, R. (2003). Education, equity and social cohesion: A distributional approach. Compare, 33, 453-470.

Grzywacz, J. G., \& Marks, N. F. (2000). Reconceptualizing the work-family interface: An ecological perspective on the correlates of positive and negative spillover between work and family. Journal of Occupational Health Psychology, 5(1), 111-126.

Han, S. J., \& Shim, Y. H. (2010). Redefining second modernity for East Asia: A critical assessment. British Journal of Sociology, 61, 465-487.

Hewison, K. (2004). Crafting Thailand's new social contract. Pacific Review, 17, 303-322.

Hewison, K. (2005). Neo-liberalism and domestic capital: The political outcomes of the economic crisis in Thailand. Journal of Development Studies, 41, 310-336.

Ho, S. C., \& Chan, C. F. (2003). In search of a competitive policy in a competitive economy: The case of Hong Kong. Journal of Consumer Affairs, 37(1), 68-85.

Holliday, I. (2000). Productivist welfare capitalism: Social policy in East Asia. Political Studies, 48, $706-723$.

Hsieh, M. F. (2011). Similar opportunities, different responses: Explaining the divergent patterns of development between Taiwan and South Korea. International Sociology, 26, 364-391.

Huang, S., \& Hsu, C. H. C. (2005). Mainland Chinese residents' perceptions and motivations of visiting Hong Kong: Evidence from focus group interviews. Asia Pacific Journal of Tourism Research, 10, 191-205.

Huang, C. C., \& Ku, Y. W. (2011). Effectiveness of social welfare programme in East Asia: A case study of Taiwan. Social Policy and Administration, 45, 733-751.

Hulse, K., \& Stone, W. (2007). Social cohesion, Social capital and social exclusion: A cross-cultural comparison. Policy Studies, 28, 109-126. 
Hundley, G. (2001). Domestic division of labor and self/organizationally employed differences in job attitudes and earnings. Journal of Family and Economic Issues, 22, 121-139.

Husband, C., \& Alam, Y. (2011). Social cohesion and counter-terrorism: A policy contradiction?. Bristol, UK: Policy.

Hwang, K. K. (2000). Chinese relationalism: Theoretical construction and methodological considerations. Journal for the Theory of Social Behavior, 30, 155-176.

Jackson, T., Chen, H., Guo, C., \& Gao, X. (2006). Stories we love by: Conceptions of love among couples from the People's Republic of China and the United States. Journal of Cross-Cultural Psychology, 37, 446-464.

Janmaat, J. G. (2011). Social cohesion as a real-life phenomenon: Assessing the explanatory power of the universalist and particularist perspectives. Social Indicators Research, 100, 61-83.

Jenson, J. (2003). New routes to social cohesion? Citizenship and the social investment state. Canadian Journal of Sociology, 28, 77-99.

Jongudomkarn, D., \& Camfield, L. (2006). Exploring the quality of life of people in North Eastern and Southern Thailand. Social Indicators Research, 78, 489-529.

Jung, E., \& Cheon, B. Y. (2006). Economic crisis and changes in employment relations in Japan and Korea. Asian Survey, 46, 457-476.

Kalish, Y. (2008). Bridging in social networks: Who are the people on structural holes and why are they there? Asian Journal of Social Psychology, 11, 53-66.

Keyes, C. L. M., \& Shapiro, A. D. (2004). Social well-being in the United States: A descriptive epidemiology. In O. G. Brim, C. D. Ryff, \& R. C. Kessler (Eds.), How healthy are we: A national study of well-being at midlife (pp. 350-372). Chicago, IL: University of Chicago Press.

Kim, A. E. (2004). The social perils of the Korean financial crisis. Journal of Contemporary Asia, 34, 221-337.

Kim, Y. S. (2010). Institutions of interest representation and the welfare state in post-democratization Korea. Asian Perspective, 34, 159-189.

Kim, S. S., Sun, H., \& Ap, J. (2008). Is there competition in the exhibition market in Asia? Analysis of the positioning of major Asia exhibition host Cities. Asia Pacific Journal of Tourism Research, 13, $205-227$.

Kinnunen, U., \& Mauno, S. (1998). Antecedents and outcomes of work-family conflict among employed women and men in Finland. Human Relations, 51, 157-177.

Knecht, M. K., Bauer, G. F., Gutzwiller, F., \& Hämmig, O. (2011). Persistent work-life conflict and health satisfaction: A representative longitudinal study in Switzerland. BMC Public Health, 11, 271.

Kuan, H. C., \& Lau, S. K. (2002). Between liberal autocracy and democracy: Democratic legitimacy in Hong Kong. Democratization, 9, 58-76.

Kung, W. W., Hung, S. L., \& Chan, C. L. W. (2004). How the socio-cultural context shapes women's divorce experience in Hong Kong. Journal of Comparative Family Studies, 35, 33-50.

La Grange, A. (2011). Neighbourhood and class: A study of three neighbourhoods in Hong Kong. Urban Studies, 48, 1181-1200.

La Grange, A., \& Yip, N. M. (2001). Social belonging, social capital and the promotion of home ownership: A case study of Hong Kong. Housing Studies, 16, 291-310.

Lang, G., Chiu, C., \& Pang, M. (2001). Impact of plant relocation to China on manufacturing workers in Hong Kong. In P. T. Lee (Ed.), Hong Kong reintegration with China: Political, social, and cultural dimensions (pp. 109-127). Hong Kong: University of Hong Kong Press.

Laurence, J. (2011). The effect of ethnic diversity and community disadvantage on social cohesion: A multilevel analysis of social capital and interethnic relations in UK communities. European Sociological Review, 27, 70-89.

Lawler, E. J., Thye, S. R., \& Yoon, J. (2009). Social commitments in a depersonalized world. New York: Russell Sage.

Lee, R. M., \& Robbins, S. B. (1998). The relationship between social connectedness and anxiety, selfesteem and social identity. Journal of Counseling Psychology, 45, 338-345.

Lei, T. (1994). Being and becoming moral in a Chinese culture: Unique or universal? Cross-Cultural Research, 28, 58-91.

Letki, N. (2008). Does diversity erode social cohesion? Social capital and race in British neighbourhoods. Political Studies, 56, 99-126.

Leung, T. T. F., \& Wong, H. (2005). Community reactions to the SARS Crisis in Hong Kong: Analysis of a time-limited counseling hotline. Journal of Human Behavior in the Social Environment, 12(1), 1-12.

Levande, D. I., Herrick, J. M., \& Sung, K. T. (2000). Eldercare in the United States and South Korea. Journal of Family Issues, 21, 632-651. 
Lew, S. C., Choi, W. Y., \& Wang, H. S. (2011). Confucian ethics and the spirit of capitalism in Korea: The Significance of Filial Piety. Journal of East Asian Studies, 11, 171-196.

Li, K. W., Liu, T., Lam, H. K., \& Wang, L. (2011). Economic integration of mainland China and the Hong Kong SAR: An analysis of growth attributes. Chinese Economy, 44, 92-114.

Lin, W. L., \& Lin, P. (2001). Emergence of the greater china circle economies: Cooperation versus competition. Journal of Contemporary China, 10, 695-710.

Lin, K., Xu, Y., Huang, T., \& Zhang, J. (2013). Social exclusion and its causes in East Asian Societies: Evidence from SQSQ survey data. Social Indicators Research, 112, 641-660.

Lin, J. P., \& Yi, C. C. (2011). Filial norms and intergenerational support to aging parents in China and Taiwan. International Journal of Social Welfare, 20, S109-S120.

Loh, C., \& Foong, K. (2005). Hong Kong as a world city: Assessing its attractiveness to global talent. Hong Kong: Civic Exchange.

Lu, J. F. R., \& Hsiao, W. C. (2003). Does universal health insurance make health care unaffordable? Lessons from Taiwan. Health Affairs, 22(3), 77-88.

Ma, N. (2009). Reinventing the Hong Kong state or rediscovering it? From low interventionism to eclectic corporatism. Economy and Society, 38, 492-519.

Ma, N. (2011). Value changes and legitimacy crisis in post-industrial Hong Kong. Asian Survey, 51, 683-712.

Ma, J. L. C., Wong, T. K. Y., Lau, Y. K., \& Pun, S. H. (2009). Perceived family functioning and family resources of Hong Kong families: Implications for social work practice. Journal of Family Social Work, 12, 244-263.

Maloutas, T., \& Maloutas, M. P. (2004). The glass menagerie of urban governance and social cohesion: Concepts and stakes/concepts as stakes. International Journal of Urban and Regional Research, 28, $449-465$.

Markus, G. B. (2001). American individualism reconsidered. In J. H. Kukinski (Ed.), Citizens and politics: Perspectives from political psychology (pp. 401-432). Cambridge, UK: Cambridge University Press.

Mason, A. (2010). Integration cohesion and national identity: Theoretical reflections on recent British policy. British Journal of Political Science, 40, 857-874.

McManus, K., Korabik, K., Rosin, H. M., \& Kellway, E. K. (2003). Employed mothers and the work-family interface: Does family structure matter? Human Relations, 55, 1295-1324.

Miller, H. T., \& Fox, C. J. (2007). Postmodern public administration. Armonk, NY: Sharpe.

Mocan, H. N., Tekin, E., \& Zax, J. S. (2003). The demand for medical care in urban China. World Development, 32, 289-304.

Muthen, L. K., \& Muthen, B. O. (2006). Mplus user's guide. Los Angeles, CA: Muthen \& Muthen.

Ng, C. H., \& Wong, T. W. P. (1999). The ethos of the Hong Kong people: Taking stock in 1997. In S. K. Lau, M. K. Lee, P. S. Wan, \& S. L. Wong (Eds.), Indicators of social development: Hong Kong 1997 (pp. 233-253). Hong Kong: Hong Kong Institute of Asia-Pacific Studies, Chinese University of Hong Kong.

Oh, M., \& Arditi, O. (2010). Self-cultivation as a microphysics of reverence: Toward a Foucauldian understanding of Korean culture. Philosophy East and West, 60, 20-39.

O’Hara, K. (2011). Conservatism. London: Reaktion.

Ohmer, M. L. (2007). Citizen participation in neighborhood organizations and its relationship to volunteers' self- and collective efficacy and sense of community. Social Work Research, 31, 109-120.

Overholt, W. H. (2004). Hong Kong at the crossroads. Santa Monica, CA: RAND.

Peng, I. (2011). The good, the bad and the confusing: The political economy of social care expansion in South Korea. Development and Change, 42, 905-923.

Podsakoff, P. M., MacKenzie, S. B., \& Podsakoff, N. P. (2003). Common method biases in behavioral research: A critical review of the literature and recommended remedies. Journal of Applied Psychology, 88, 879-903.

Ramesh, M. (2003). Health policy in the Asian NIEs. Social Policy and Administration, 37, 361-375.

Ravanera, Z. R., Rajalton, F., \& Turcotta, P. (2003). Youth integration and social capital: An analysis of the Canadian social surveys in time use. Youth \& Society, 35, 158-182.

Robinson, D. (2005). The search for community cohesion: Key themes and dominant concepts of the public policy agenda. Urban Studies, 42, 1418-1427.

Rossi, A. S. (2001). Developmental roots of adult social responsibility. In A. S. Rossi (Ed.), Caring and doing for others: Social responsibility in the domain of family, work, and community (pp. 227-320). Chicago, IL: University of Chicago Press.

Sanchez, M. L. M. (2007). The effect of social capital in Women's participation in the labor force in Mexico: A neighborhood in Monterry. Doctoral Dissertation, University of Texas at Arlington. 
Schmid, K., Hewstone, M., Tausch, N., Cairns, E., \& Hughes, J. (2009). Antecedents and consequences of social identity complexity: Intergroup contact, distinctiveness threat and outgroup attitudes. Personality and Social Psychology Bulletin, 35, 1085-1098.

Shin, K. Y. (2012). The dilemma of Korea's new democracy in an age of neoliberal globalisation. Third World Quarterly, 33, 293-309.

Sing, M. (2004). Hong Kong's tortuous democratization: A comparative analysis. London: RoutledgeCurzon.

Sing, M. (2006). The legitimacy problem and democratic reform in Hong Kong. Journal of Contemporary China, 15, 517-532.

Sobolewski, J. M., \& Amato, P. R. (2007). Parents' discord and divorce, parent-child relationships and subjective well-being in the early adulthood: Is feeling close to two parents always better than feeling close to one? Social Forces, 85, 1105-1124.

Spector, P. E., Cooper, C. L., Poelmans, S., Allen, T. D., O’Driscoll, M., Sanchez, J. I., et al. (2004). A cross-national comparative study of work-family stressors, working hours, and well-being: China and Latin America versus the Anglo World. Personnel Psychology, 57, 119-142.

Sturm, D. (1998). Solidarity and suffering: Toward a politics of relationality. Albany, NY: State University of New York Press.

Suh, M. G. (2010). Distributive equity and class position in South Korea. Korea Observer, 41, 53-67.

Sung, M. (2010). The psychiatric power of neoliberal citizenship: The North Korean human rights crisis, North Korean settlers, and incompetent citizens. Citizenship Studies, 14, 127-144.

Tan, S. H. (2003). Confucian democracy: A Deweyan reconstruction. Albany, NY: State University of New York.

Tang, K. L. (2006). Asset building and its determinants: Lessons from social security reform in China and Hong Kong. Social Development Issues, 28(2), 40-56.

Thye, S. R., Yoon, J., \& Lawler, E. J. (2002). The theory of relational cohesion: Review of a research program. Advances in Group Processes, 19, 139-166.

Tiwsakul, R. A., \& Hackley, C. (2012). Postmodern paradoxes in Thai-Asian consumer identity. Journal of Business Research, 65, 490-496.

Tolsma, J., van der Meer, T., \& Gesthuizen, M. (2009). The impact of neighborhood and municipality characteristics on social cohesion in the Netherlands. Acta Politica, 44, 286-313.

Tsai, M. C. (2006). Sociable resources and close relationships: Intimate relatives and friends in Taiwan. Journal of Social and Personal Relationships, 23, 151-169.

Ulbig, S. G. (2002). Policies, procedures, and people: Sources of support for government? Social Science Quarterly, 83, 789-809.

Uzzell, D., Pol, E., \& Badenas, D. (2002). Place identification, social cohesion, and environmental sustainability. Environment and Behavior, 34, 26-53.

van Hemert, D. A., van de Viver, F. J. R., Poortinger, Y. H., \& Georgas, J. (2002). Structural and functional equivalence of the Eysenck Personality Questionnaire within and between-countries. Personality and Individual Differences, 33, 1229-1249.

Vasi, I. B., \& Macy, M. (2003). The Mobilizer's dilemmas: Crisis, empowerment, and collective action. Social Forces, 82, 979-998.

Wang, J. H. (2001). Contesting flexibility: The restructuring of Taiwan's labor reactions and spatial organization. International Journal of Urban and Regional Research, 25, 346-378.

Wang, C. H. (2003). Taipei as a global city: A theoretical and empirical examination. Urban Studies, 40, 309-334.

Westerman, C. Y. K., Park, H. S., \& Lee, H. E. (2007). A test of equity theory in multidimensional friendships: A comparison of the United States and Korea. Journal of Communication, 57, 576-598.

Wharton, A. S., \& Blair-Loy, M. (2006). Long work hours and family life: A cross-national study of employees' concerns. Journal of Family Issues, 27, 415-436.

Wilkinson, S. I. (2009). Riots. Annual Review of Political Science, 12, 329-343.

Wilson, J. (2000). Volunteering. Annual Review of Sociology, 26, 215-240.

Wilson, J., \& Musick, M. A. (1999). Attachment to volunteering. Sociological Forum, 14, 243-272.

Wong, T. W. P. (1995). Economic culture and distributive justice. In S. Lau, M. Lee, P. Wan, \& S. Wong (Eds.), Indicators of social development: Hong Kong 1993 (pp. 367-398). Hong Kong: Hong Kong Institute of Asian-Pacific Studies.

Wong, H. (2011). Quality of life of poor people living in remote areas in Hong Kong. Social Indicators Research, 100, 435-450.

Woo, M. (2011). A newly emerging small welfare state and social cleavage: The Korean Case. Korea Observer, 42, 645-676. 
Yamaoka, K. (2008). Social capital and health and well-being in East Asia: A population-based study. Social Science and Medicine, 66, 883-899.

Zagorski, K. (1999). Egalitarianism, perception of conflicts, and support for transformation in Poland. In S. Svallfors \& P. Taylor-Gooby (Eds.), The end of the welfare state? Responses to state retrenchment (pp. 190-217). London: Routledge.

Zeigler, H. (1988). Pluralism, corporatism, and confucianism: Political association and conflict regulation in the United States, Europe, and Taiwan. Philadelphia, PA: Temple University Press. 